\title{
REFERENCES
}

Bibik, 2018 - Nova ukrainska shkola: poradnyk dlia vchytelia / za zah.red. N.M.Bibik. - Kyiv: Litera LTD, 2018. $160 \mathrm{~s}$.

Bilonozhko, 2015 - Bilonozhko O. A. Formuvannia usnoho ta pysemnoho movlennia na urokakh matematyky / O. A. Bilonozhko // Matematyka v shkolakh Ukrainy. - 2015. - №6. - S. 10-11.

Bohdanovych, 1998 - Bohdanovych M. V. ta in. Metodyka vykladannia matematyky v pochatkovykh klasakh : Navchalnyi posibnyk dlia studentiv pedahohichnykh navchalnykh zakladiv. // M. V. Bohdanovych, M. V. Kozak, Ia. A. Koval. - K.: «A.S.K.», 1998. - 342 s.

Derzhavnyi standart..., 2018 - Derzhavnyi standart pochatkovoi osvity // Typovi osvitni prohramy dlia zakladiv zahalnoi serednoi osvity : 1-2 klasy. - K. : TD «OSVITA-TsENTR+», 2018.- S. 92-121.

Koval, 2011 - Koval L. V. Metodyka navchannia matematyky v pochatkovii shkoli : teoriia i praktyka / L. V. Koval, S. O. Skvortsova. - Kharkiv : ChP «Prynt Lider», 2011. - 414 s.

Koval, 2015 - Koval L. V. Pochatkova matematychna osvita v umovakh reformuvannia vitchyznianoi shkilnoi haluzi / L. V. Koval // Naukovi zapysky Berdianskoho derzhavnoho pedahohichnoho universytetu. Ser : Pedahohichni nauky. - 2015. - Vyp. 1. - S. 86-93.

Lokshyna, 2009 - Lokshyna O. I. Zmist shkilnoi osvity v krainakh Yevropeiskoho Soiuzu : teoriia i praktyka (druha polovyna XX - pochatok XXI st.) : monohrafiia / O. I. Lokshyna. - K. : Bohdanova A.M., 2009. - 404 s.

Onopriienko, 2014 - Onopriienko O. Kompetentnisnyi pidkhid do navchannia matematyky / O. Onopriienko, N. Lystopad, S. Skvortsova. - K.: Redaktsii hazet z doshkilnoi ta pochatkovoi osvity, 2014. - $128 \mathrm{~s}$.

Skvortsova, 2013 - Skvortsova S.O. Pidhotovka maibutnikh uchyteliv pochatkovykh klasiv do navchannia molodshykh shkoliariv rozviazuvaty siuzhetni matematychni zadachi : [monohrafiia] / S.O. Skvortsova, Ya.S. Haievets. - Kh. : Ranok -NT, 2013. - 332 s.

Typova osvitnia prohrama..., 2018 - Typova osvitnia prohrama dlia zakladiv zahalnoi serednoi osvity (rozroblena pid kerivnytstvom O. Ya. Savchenko). - K. : TD «OSVITA-TsENTR+», 2018.- S. 190-237.

Typova osvitnia prohrama..., 2018 - Typova osvitnia prohrama dlia zakladiv zahalnoi serednoi osvity, 1-2 klas (rozroblena pid kerivnytstvom R. B. Shyiana). - K. : TD «OSVITA-TsENTR+», 2018.- S. 122-189.

\section{УДК 159.964.21-053.6:316.28-04722}

\section{Тетяна Пономаренко,} аспірант кафедри політичної психологї та сочіально-правових технологій ,

Національного педагогічного університету ім. М.П. Драгоманова.

\section{DOI 10.31470/2308-5126-2019-45-2-85-92}

\author{
E-mail: solovei24081994@gmail.com
}

ORCID 0000-0003-0949-1611

\section{РІВЕНЬ КОМУНІКАТИВНОЇ КОМПЕТЕНТНОСТІ ОСОБИСТОСТІ ЯК ДЕТЕРМІНАНТА КОНФЛІКТОЛОГІЧНОЇ АКТИВНОСТІ ПІДЛІТКІВ}

\begin{abstract}
Стаття присвячена висвітленню проблеми міжособистісного спілкування та розвитку комунікативних умінь підлітків, а також дослідженню впливу комунікабельності особистості на виникнення конфліктів у підлітковому віці. Саме міжособистісне спілкування і є провідною діяльністю иього віку, а конфліктологічна активність підлітків найчастіше пов'язана з постійною переоцінкою иінностей, яка відбувається в процесі спілкування з соиіальним оточенням, формуванням самосвідомості, появою певних установок, стереотипів і власного бачення ситуації. У статті описане дослідження, яке демонструє рівень комунікабельності учнів, рівень їхнього комунікативного контролю, рівень конфліктності, а також стиль поведінки в конфліктній ситуації. Розроблено автором методичні рекомендації для батьків і вчителів щзодо розвитку комунікативної компетентності та психопрофілактики виникнення конфліктів у підлітковому вiųi.
\end{abstract}

Ключові слова: комунікативна компетентність, міжособистісне спілкування, комунікабельність, конфлікт, стиль поведінки у конфлікті, комунікативний контроль, профілактика конфліктів.

This article is about the problem of interpersonal communication and the development of communicative skills of adolescents. The interpersonal communication and the construction of interpersonal interlocutors with a social environment is the leading activity of adolescence. Conflict activity of adolescents is most often associated with revaluation of values that occurs in the process of communicating with the social environment, the formation of self- 
consciousness, the emergence of certain settings, stereotypes and their own vision of the situation. One of the reasons for conflicts in adolescence is that they can not build, explain or argue their own opinion. Therefore, there is a need for the development of communicative knowledge, skills and abilities of counterparts. Communication skills will help teens to prevent conflicts in their everyday life.

This article describes the research about influence of communicability of the person on the resolution of conflicts. 79 students participated in this research (42 girls and 37 boys, aged 12-14 years). We use four methods: Methods for assessing the level of communicability ( $V$. Ryakhovsky test), Methods of self-control evaluation in communication (M.Snayder), Test diagnostic the level of conflict of personality and a method for determining the behavior style in conflict Test K. Thomas. In the research we identified the level of pupil's communication skills, the level of their communicative control, the level of conflict of adolescents and the style of behavior that they choose in a conflict situation. We create and describe recommendations for parents and teachers on the development of communicative competence and prevention of conflicts in adolescence. We found that the low level of development of communicative skills of adolescents may also be related to the lack of communication between parents with children, therefore, we see further scientific activity in the study of this problem, as well as the reasons for its occurrence.

Keywords: communicative competence, interpersonal communication, sociability, conflict, style of conflict behavior, communicative control, prevention of conflicts.

Постановка проблеми. Спілкування відіграє важливу роль у житті кожної людини. Ми активно спілкуємось у сімейному колі, у дитячому садочку, згодом у шкільному колективі та 3 друзями, навчаючись в університеті та на роботі. Із кожним віковим періодом наша комунікація виходить на новий рівень та відіграє більш вагому роль. Згодом саме від комунікативної компетентності й буде залежати вміння будувати і висловлювати власну думку, знаходити спільну мову 3 людьми, аргументувати власну позицію, навички коворкінгу та певною мірою успішність професійної діяльності.

Високий рівень розвитку комунікативних навичок дозволяє особистості не лише легко взаємодіяти в суспільстві, а навіть запобігати конфліктам та вирішувати конфліктні ситуації.

Аналіз останніх досліджень $\boldsymbol{i}$ публікацій вказує на увагу до проблеми комунікативної компетентності особистості. Протягом останніх десяти років цю проблему активно вивчають зарубіжні дослідники (Д. Адріан, Л. Бахман, М. Доррі, Ф. Лейл, А. Палмер та ін.), російські науковці (Л. Булигіна, Л. Войтенко, О. Желнова, Ю. Жуков, С. Курілова, О. Шумілова та ін.) і українські вчені (Т. Дрозд, T. Кобзар, І. Когут, С. Маща, О. Низовець, Ю. Паскевська, Л. Пляка, О. Смирнова, I. Черезова). Дослідженням комунікативної компетентності у контексті ії впливу на вирішення конфліктів займалися М. Авдєєва, А. Аросланова, Т. Свтушенко, Н. Ларіна, Л. Онуфрієва, Л. Пашко, С. Ренке, О. Руденко, О. Тармаєва, К. Тутова та ін. вчені.

Mema cmammi полягає у виявленні кореляції рівня комунікативної компетентності особистості 3 виникненням конфліктів у підлітковому віці та розробці рекомендацій для батьків та вчителів щодо розвитку комунікативних навичок та психопрофілактики виникнення конфліктів у підлітковому віці.

Виклад основного матеріалу. Із віком потреба особистості в спілкуванні поглиблюється і стає все більш значущою. Одним із піків такого розвитку є саме підлітковий період. Потребу в спілкуванні можна пояснити декількома причинами. Найбільш важливою із них, на думку А. Мудрика, є постійний фізичний і розумовий розвиток, і в зв'язку з цим розширення інтересів підлітка, зростання інтересу до світу [Мудрик, 2001: с. 114]. Також провідною діяльністю цього вікового періоду $є$ міжособистісне спілкування у колі батьків, вчителів, друзів чи однолітків, яке, у свою чергу, потребує відповідних знань, умінь і навичок. 
Необхідно зазначити, що комунікативна компетентність являє собою вміння спілкуватися як усно, так і письмово, доводити власну думку, адаптуватися в мовному середовищі в будь-якій соціальній ситуації; вона забезпечує можливість безпосереднього спілкування. Тому оволодіти комунікативною компетентністю надзвичайно важливо саме в підлітковому віці. Адже у цей віковий період спілкування - одна 3 найважливіших потреб, яка супроводжується сукупністю переживань.

У працях А. Реана виокремлено три основні функції спілкування підлітків: 1) важливе специфічне джерело інформації; 2) специфічний вид міжособистісних стосунків, який виробляє необхідні навички соціальної взаємодії; 3) специфічний вид емоційного контакту, який дає відчуття емоційного благополуччя [Реан, 2003 : c. 266].

Низький рівень розвитку комунікативних знань, умінь та навичок не дає можливості підлітку повною мірою реалізувати всі функції спілкування. Варто також зазначити, що окрім спілкування з ровесниками, провідною діяльністю цього віку є побудова міжособистісних стосунків з оточенням.

Негативний вплив на процес взаємодії дитини з батьками, вчителями та однолітками мають міжособистісні конфлікти. Конфлікти в психологічній науці традиційно визначають як зіткнення протилежно налаштованих сторін, інтересів, думок, поглядів, установок, серйозні розбіжності. Вони часто виникають через низький рівень комунікативних знань, умінь і навичок. Причиною виступає саме недостатнє уміння правильно, логічно i лаконічно побудувати, висловити чи аргументувати власну думку, а також низький рівень комунікативного контролю та невміння слухати співрозмовника. Через це домовитися, словесно вирішити ситуацію чи знайти компроміс стає просто неможливо. Тому вважаємо за необхідне дослідити взаємозв'язок комунікативної компетентності з виникненням конфліктів у підлітковому віці.

У ході проведеного нами дослідження рівня розвитку комунікативної компетентності та особливостей конфліктологічної поведінки, у якому взяли участь учні 8-А, 8-Б, 8-В класів Білоцерківської спеціалізованої школи № 93 поглибленим вивченням іноземних мов - (кількість досліджуваних - 79 осіб, з них: 42 дівчини і 37 юнаків, - віком 12-14 років), ми за допомогою Методики оцінки рівня комунікабельності (тест В. Ряховского) [Зозуляк-Случик, 2011: c. 153] оцінили рівень комунікабельності обстежуваних. Проаналізувавши дані, ми отримали такі результати (таблиця 1).

Для зручності сприймання і розуміння ми об’єднали деякі рівні і встановили, що:

Низький рівень комунікабельності продемонстрували 29 осіб - 37 \%. Ці показники свідчать, що таким учням складно знаходити спільну мову з однолітками, висловлювати власну думку і аргументувати ії.

Середній рівень комунікабельності ми діагностували в 39 осіб - 50\%. Такі діти досить комунікабельні, готові до нових знайомств, легко товаришують один 3 одним.

Високий рівень комунікативної компетентності мають лише 11 осіб - $13 \%$. Ці учні зазвичай активні, постійно беруть участь у різних конкурсах та заходах самодіяльності, люблять виступати на сцені. Для них не є проблемою домовитись зі співрозмовником і отримати бажане. 
Таблиця 1

Співвідношення рівня розвитку комунікативних навичок у підлітків

(за методикою В. Ряховского)

\begin{tabular}{|l|l|l|}
\hline \multicolumn{1}{|c|}{ Результати методики } & \multicolumn{1}{c|}{ Кількість осіб } & \multicolumn{1}{c|}{$\%$} \\
\hline Дуже низький рівень & 0 & $0 \%$ \\
\hline Низький рівень & 13 & $17 \%$ \\
\hline Помірний рівень & 16 & $20 \%$ \\
\hline Середній рівень & 26 & $33 \%$ \\
\hline Достатній рівень & 13 & $17 \%$ \\
\hline Високий рівень & 11 & $13 \%$ \\
\hline Дуже високий рівень & 0 & $0 \%$ \\
\hline
\end{tabular}

Хочемо зазначити, що, проаналізувавши результати нашого дослідження, ми констатували, що ці показники $є$ наслідками цілого ряду причин, серед яких: тривожність учнів, невпевненість у собі, недостатня кількість спілкування, невміння доводити і аргументувати власну позицію, конфлікти і непорозуміння з батьками, відсутність підтримки з боку батьків та інших.

Також за допомогою Методики оцінки самоконтролю у спілкуванні (М. Снайдера) [Райгородский, 1998: с. 558] ми вивчили рівень комунікативного контролю учнів. Результати дослідження за методикою представлені на рисунку 1.

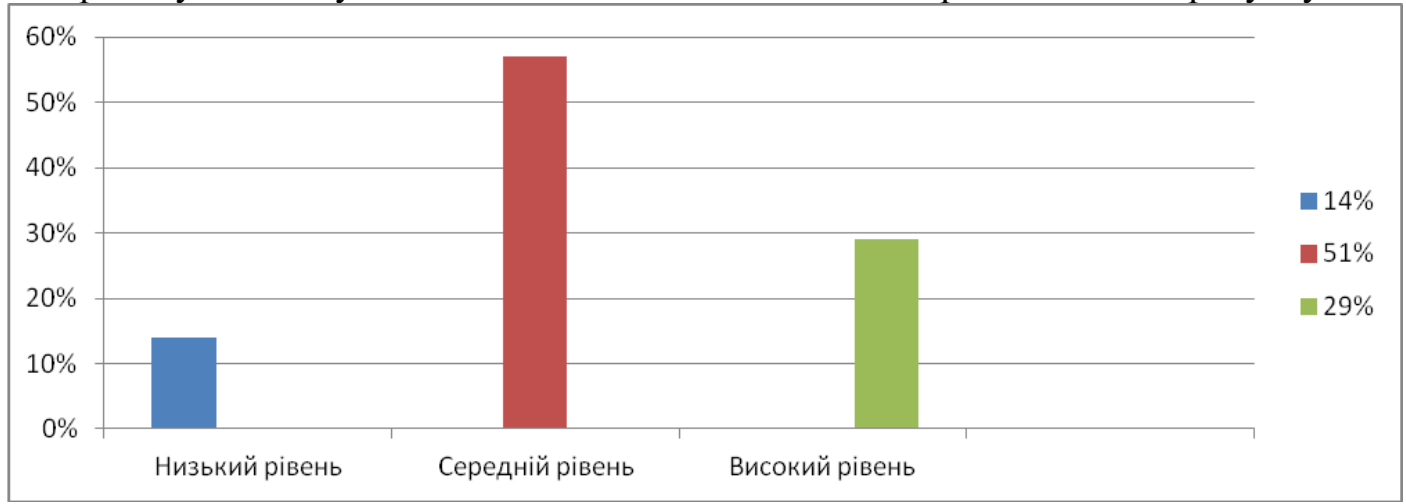

Рис. 1. Співвідношення рівня розвитку комунікативного самоконтролю у підлітків (за методикою М. Снайдер) (у\%).

Зокрема нами встановлено, що:

11 осіб - 14 \% мають низький комунікативний контроль. Такі учні поводять себе нестримано на уроках, не обмежують себе у висловлюваннях, - як на адресу однолітків, так і на адресу людей старших за віком. Така поведінка часто пов'язана 3 проблемами у вихованні, а також із неадекватною самооцінкою особистості. Такі підлітки досить часто використовують нецензурну лексику в спілкуванні.

45 - 57 \% мають середній комунікативний контроль. Такі люди щирі, але не стримані у своїх емоційних проявах, зважають у своїй поведінці на оточення. Ці учні досить легко приймають сторону i модель поведінки людини, яка $є$ для них авторитетом і має певний вплив.

23 - $29 \%$ учасники мають високий комунікативний контроль. Такі люди легко входять у будь-яку роль, гнучко реагують на зміну ситуації, добре відчувають i навіть можуть передбачити враження, яке вони справляють на оточення. Ці учні тактовні, контролюють свої висловлювання і 3 повагою спілкуються $з$ іншими. 
Наступним кроком - за допомогою Тесту діагностики рівня конфліктності особистості [Зозуляк-Случик, 2011: c. 162], - ми визначили рівень конфліктності кожного учня. Результати методики представлені на рисунку 2.

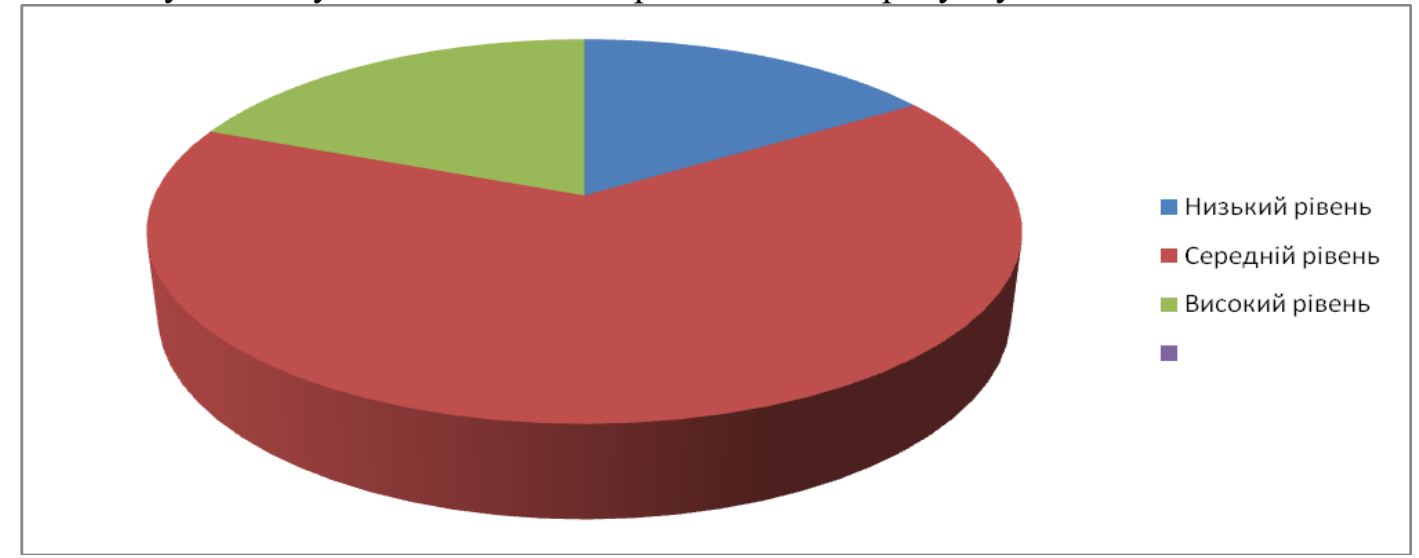

Рис. 2. Співвідношення рівнів конфліктності особистості у підлітків ( у \%).

Проаналізувавши отримані результати, ми можемо зробити такі висновки:

Низький рівень мають 13 осіб - 16 \%. Такі підлітки тактовні й миролюбні, уникають суперечок, конфліктів і критичних ситуацій - у школі та вдома. Проте інколи їх можуть називати пристосуванцями через те, що ті не прагнуть відстоювати свої права, прислуховуючись до чужих рішень.

Середній рівень має 51 особа - 65 \%. Таких учнів - вважають конфліктними людьми. Але насправді вони конфліктують тільки в тому випадку, якщо немає іншого виходу й інші засоби вирішення проблеми вичерпані. Вони - твердо відстоюють власну думку, не виходячи при цьому за рамки коректності. Усе це викликає до них - повагу.

Високий рівень демонструють 15 осіб - $19 \%$. Суперечності і конфлікти - це повітря, без якого - такі підлітки не можуть жити. Вони люблять критикувати інших, але тоді, коли їм - це вигідно. Якщо ж вони чують зауваження на свою адресу, готові «з'їсти живцем» того, хто критикує. Їхня критика - заради критики, а не заради справи. Досить важко доводиться тим, хто поруч 3 ними в школі та вдома. Їхня нестриманість відштовхує людей.

Також ми визначили стиль поведінки в конфлікті кожного учня за допомогою Тесту К. Томаса [Карелина, 2001: с. 69] (таблиця 2).

Таблиця 2

\section{Співвідношення стилю поведінки в конфліктній ситуації у підлітків} (за методикою «Тест К. Томаса») .

\begin{tabular}{|l|c|c|}
\hline \multicolumn{1}{|c|}{$\begin{array}{c}\text { Стиль поведінки у } \\
\text { конфліктній ситуації }\end{array}$} & Кількість осіб & \% \\
\hline Суперництво & 13 & $16 \%$ \\
\hline Співробітництво & 14 & $17 \%$ \\
\hline Компроміс & 21 & $28 \%$ \\
\hline Уникнення & 17 & $21 \%$ \\
\hline Поступливість & 14 & $17 \%$ \\
\hline
\end{tabular}


Стиль суперництва (конкуренції) 13 осіб (16\%) - такий підліток, - дуже активний i воліє йти до вирішення конфлікту власним шляхом. Він не дуже зацікавлений у співпраці з іншими людьми, зате здатен на вольові рішення.

Для стилю співробітницттва - 14 осіб (17\%) характерна активна робота 3 вирішення проблеми, яка поєднує бажання максимально задовольнити як свої інтереси, так і інтереси іншої сторони.

Стиль компромісу - 21 особа (28\%) полягає в тому, що кожна зі сторін поступається частиною своїх інтересів, очікуючи того самого від іншої сторони.

Стиль пристосування - 14 осіб (17\%) означає, що особистість діє спільно 3 іншою людиною, навіть не намагаючись відстоювати власні інтереси.

Стиль уникнення - 17 осіб (27\%) - даний стиль реалізується тоді, коли учень не відстоює свої права, не співпрацює ні з ким для вироблення рішення проблеми або просто уникає конфлікту.

Проаналізувавши отримані результати, ми встановили, що підлітки використовують всі стилі поведінки в конфліктній ситуації, але перевагу вони зазвичай надають стилю компромісу або уникнення, рідше трапляється стиль суперництва, співробітництва та пристосування. Учні 3 високим рівнем комунікабельності найчастіше обирають стиль співробітництва чи компромісу, 3 середнім і низьким рівнями - суперництва, уникнення і пристосування.

Застосувавши коефіцієнт кореляції Пірсона, який становить $\mathbf{r}_{\mathbf{x y}}=$ 2622.57 / (58.17 x 54.54) = $\mathbf{- 0 . 8 2 7 ~} 7$ 3, ми довели, що рівень комунікативної компетентності у групи досліджуваних корелює з рівнем конфліктності особистості. Що нижчим $є$ рівень комунікабельності особистості, то вищою $є$ ймовірність виникнення конфліктів у підлітковому віці.

Таким чином, спираючись на отримані нами результати теоретичного та емпіричного дослідження, ми встановили, що низький рівень комунікативної компетентності впливає на виникнення конфліктів у підлітковому віці, тому виникає необхідність у розробці й впровадженні методичних рекомендацій для батьків та вчителів щодо розвитку комунікативних навичок та психопрофілактики виникнення конфліктів у цій віковій групі.

Спираючись на роботи Л. Булигіної [Бульгина, 2013: с. 147], О. Касьянової [Касьянова, 2008: с. 79], О. Прозорої [Прозорова, 2000: с. 191], С. Банькіної [Баныкина, 1997: c. 57] та I. Долженко [Долженко, 2006: с. 34], ми розробили методичні рекомендації для батьків та вчителів щодо розвитку комунікативної компетентності та психопрофілактики виникнення конфліктів у підлітковому віці.

\section{Рекомендації для батьків:}

1. Підтримуйте і провокуйте комунікативну активність підлітка, формуйте комунікативний досвід - цікавтеся справами в школі, його хобі та інтересами.

2. 3 метою розвитку понятійного апарату та кругозору підлітка, - заохочуйте його до читання та перегляду розвиваючих передач.

3. Разом із дитиною відвідуйте кіно, виставки, театри тощо. Після перегляду обов'язково цікавтеся враженням дитини про побачене чи почуте, разом аналізуйте конфліктні ситуації з фільму чи вистави.

4. Беріть до уваги відмінність ціннісних орієнтацій у зв'язку з віком (теорія поколінь) - враховуйте цінності та інтереси підлітка.

\section{Рекомендації для вчителів:}

1. Давайте можливість дитині аргументувати власну позицію та вислухайте всіх учнів класу, які були залучені до суперечки чи стали ії свідками - на виховній 
годині обговоріть ситуацію, що склалася, і разом із учнями шукайте можливі шляхи iї вирішення.

2. Не вирішуйте проблеми в підвищеному емоційному стані, обговоріть ситуацію з учнями. При обговоренні слідкуйте за їхнім емоційним станом, контролюйте їхню поведінку, не давайте можливості переходити на крик.

3. Організовуйте тренінги та майстер-класи із залученням спеціалістів, які формуватимуть у дітей навички попередження і виходу з ситуацій конфлікту.

4. На виховних годинах демонструйте уривки 3 дитячих фільмів та мультфільмів, де є конфліктна ситуація та обговоріть іï з учнями, шукайте справжні причини конфлікту та можливі шляхи його вирішення.

Висновки. Рівень комунікативної компетентності має безпосередній вплив на рівень конфліктності особистості. Що нижчий рівень комунікабельності, то вища ймовірність виникнення конфліктів у підлітковому віці. Відповідно, високий рівень розвитку комунікативних знань, умінь і навичок дозволяє особистості не лише ефективно розв'язувати конфліктні ситуації, що склалися, але й активно запобігати їхньому виникненню. У ході бесіди з учнями ми встановили, що низький рівень розвитку комунікативних навичок підлітків може бути також пов'язаний із недостатньою кількістю спілкування батьків із дітьми, тому подальшу наукову діяльність ми вбачаємо в дослідженні цієї проблематики, а також причин іï виникнення.

\section{ЛІТЕРАТУРА}

Баныкина, 1997 - Баныкина С. В. Конфликтологическая компетентность педагога / С. В. Баныкина. Астрахань: Волга, 1997. - 124 с.

Бульгина, 2013 - Булыгина Л. Н. Формирование коммуникативной компетентности подростков в школьном обучении : дис. канд. пед. наук : 13.00.01 / Булыгина Лариса Николаевна - Тюмень, 2013. - $191 \mathrm{c.}$

Долженко, 2006 - Долженко І. В. Використання соціально-педагогічних технологій у роботі з сім'єю / I. В. Долженко // Соціальна педагогіка: теорія і практика. - 2006. - № 4. - С. 34-38.

Зозуляк-Случик, 2011 - Зозуляк-Случик Р. В. Етика соціально-педагогічної діяльності : навчальний посібник для студентів вищих навчальних закладів / Р. В. Зозуляк-Случик, Б. І. Ковбас. - Івано-Франківськ: Симфонія форте, 2011. - 212 с.

Карелина, 2001 - Карелина А. А. Психологические тесты / Тест описания поведения К. Томаса (адаптация Н. В. Гришиной) / В 2т. - М., 2001. - Т.2. С. 69-77.

Касьянова, 2008 - Касьянова О. В. Особливості формування комунікативної компетентності у молодших підлітків в умовах громадського дитячого об'єднання / О. В. Касьянова // Освіта на Луганщині. 2008. - № 1 (28). - С. 79-84.

Мудрик, 2001 - Мудрик А. В. Общение в процессе воспитания / А. В. Мудрик. - М.: Педагогическое общество России, 2011. - 320 с.

Прозорова, 2000 - Прозорова Е. В. Педогогические условия развития комуникативной компетентності// Мир психологи. - 2000. - № 2. - С.191-202.

Райгородский, 1998 - Райгородский Д. Я. Практическая психодиагностика. Методики и тесты. Учебное пособие / Д. Я. Райгородский. - Самара: Издательский Дом «БАХРАХ», 1998. - 672 с.

Реан, 2003 - Реан А. А. Психология подростка / Под. ред А. А. Реана. - СПб.: Прайм-ЕВРОЗНАК, 2003. $480 \mathrm{c}$.

\section{REFERENCES}

Banykina, 1997 - Banykina S. V. Konfluktolohycheskaia kompetentnost pedahoha / S. V. Banykina. - Astrakhan: Volha, 1997. - $124 \mathrm{~s}$.

Bulyhina, 2013 - Bulyhina L. N. Formyrovanie kommunikatyinoy kompetentnosti podrostkov v shkolnom obuchenii : dys. kand. ped. nauk: 13.00.01 / Bulyhina Larysa Nykolaevna. - Tiumen, 2013. - $191 \mathrm{~s}$.

Dolzhenko, 2006 - Dolzhenko I. V. Vykorystannia sotsialno-pedahohichnykh tekhnolohii u roboti z simieiu / I. V. Dolzhenko // Sotsialna pedahohika: teoriia i praktyka. - 2006. - №4. - S. 34-38.

Zozuliak-Sluchyk, 2011 - Zozuliak-Sluchyk R.V. Etyka sotsialno-pedahohichnoi diialnosti : navchalnyi posibnyk dlia studentiv vyshchykh navchalnykh zakladiv / R. V. Zozuliak-Sluchyk, B. I. Kovbas. Ivano-Frankivsk: Symfoniia forte, 2011. $-212 \mathrm{~s}$. 
Karelina, 2001 - Karelina A.A. Psikholoiycheskie testy / Test opisaniia povedeniia K.Tomasa (adaptatsiia N.V.Hrishinoi) / V 2t. - M., 2001. - T.2. S.69-77.

Kasianova, 2008 - Kasianova O. V. Osoblyvosti formuvannia komunikatyvnoi kompetentnosti u molodshykh pidlitkiv v umovakh hromadskoho dytiachoho obiednannia / O. V. Kasianova // Osvita na Luhanshchyni. 2008. - № 1 (28). - S. 79-84.

Mudryk, 2001 - MudrykA.B. Obshchenie v protsesse vospitaniia / A.V. Mudryk. - M.: Pedahohicheskoe obshchestvo Rossii, 2011. - $320 \mathrm{~s}$.

Prozorova, 2000 - Prozorova Ye.V. Pedohohicheskie usloviia razvityia komunikativnoy kompetentnosti// Mir psikholohii. - 2000. - № 2. - S.191-202.

Raihorodskiy, 1998 - Raihorodskiy D. Ya. Prakticheskaia psikhodiahnostika. Metodyky i testy. Uchebnoe posobie / D. Ya. Raihorodskuy. - Samara: Izdatelskiy Dom «BAKhRAKh», 1998. - $672 \mathrm{~s}$.

Rean, 2003 - Rean A. A. Psikholohiia podrostka / Pod. red A. A. Reana. - SPb.: Praim-EVROZNAK, 2003. - 480 s.

УДК 37.091.31:004

В'ячеслав Різник,

кандидат педагогічних наук, доцент кафедри професійної освіти ДВНЗ

«Переяслав-Хмельницький державний педагогічний університет імені Григорія Сковороди».

DOI 10.31470/2308-5126-2019-45-2-92-98

Viacheslav Riznyk,

Ph.D in Pedagogy, Assosiate Professor of the Professional Education Department

SHEI «Pereiaslav-Khmelnytskyi

Hryhorii Skovoroda

State Pedagogical University».

E-mail: riznyk84@gmail.com

ORCID 0000-0002-6083-2242

Надія Різник,

старший викладач кафедри професійної освіти ДВНЗ «Переяслав-Хмельницький державний педагогічний університет імені Григорія Сковороди».

\section{E-mail: nadyariznyk@gmail.com ORCID 0000-0003-0893-9795}

Senior Lecturer of the Professional Education Department SHEI «Pereiaslav-

Khmelnytskyi Hryhorii Skovoroda

State Pedagogical University».

Оксана Перчук, старший викладач кафедри професійної освіти ДВНЗ «Переяслав-Хмельницький державний педагогічний університет імені Григорія Сковороди».
Oksana Perchuk, Senior Lecturer of the Professional Education Department SHEI «Pereiaslav-Khmelnytskyi Hryhorii Skovoroda State Pedagogical University».

E-mail: oksi011279@ gmail.com

ORCID 0000-0002-6484-7011

\section{SMART-OCВITА ЯК ВІДПОВІДЬ НА ЗАПИТИ ПРОГРЕСИВНОГО СУСПІЛЬСТВА}

У статті обтрунтовано необхідність впровадження sтаrt-освіти як відповіді на запити прогресивного суспільства. Розкрито сутність sтанt-освіти як комплексу елементів освітньої системи, щяо набувають иілісності завдяки Інтернет-мережі задля реалізаџї мети та змісту освіти. 3'ясовано, щьо smart-освіта як інновація спрямована насамперед на більш раџіональне вирімення актуальних освітніх задач за допомогою використання вже наявних ресурсів та засобів- таких як Інтернет, гаджети, мультимедійні пристрої - в навчальних цілях. Виокремлено основні риси концепції sтанt-освіти: індивідуалізація освітнього процесу; вмотивованість до навчання; адаптивність імплементації; технічне й технологічне розмаїття.

Обтрунтовано, що sтаrt-освіта завдяки прогресивності та повноцінному залученню технологій $i$ гаджетів в процес навчання здатна вплинути на студентів позитивним чином, при извому інноваційність освітнього середовища є одним із ключових мотиваційних важелів впливу. Саме інноваційність та індивідуалізацію освіти необхідно позиціонувати як альтернативу застарілому баченню в площині формальної вищої освіти.

У результаті проведеного дослідження доведено, щуо вітчизняна освітня система знаходиться в кризовому, трансформаційному стані. При цььому, перебуваючи на зламі століть, етап трансформації 